Abstracta Iranica

Revue bibliographique pour le domaine irano-aryen

Volume 34-35-36 | 2017

Comptes rendus des publications de 2011-2013

\title{
John Curtis, Nigel Tallis. The Horse. From Arabia to Royal Ascot
}

\section{Astrid Nunn}

\section{OpenEdition}

1 Journals

\section{Édition électronique}

URL : http://journals.openedition.org/abstractairanica/41642

DOI : 10.4000/abstractairanica.41642

ISSN : 1961-960X

Éditeur :

CNRS (UMR 7528 Mondes iraniens et indiens), Éditions de l'IFRI

Référence électronique

Astrid Nunn, « John Curtis, Nigel Tallis. The Horse. From Arabia to Royal Ascot», Abstracta Iranica [En ligne], Volume 34-35-36 | 2017, document 65, mis en ligne le 15 juillet 2016, consulté le 26 septembre 2020. URL : http://journals.openedition.org/abstractairanica/41642 ; DOI : https://doi.org/10.4000/ abstractairanica.41642

Ce document a été généré automatiquement le 26 septembre 2020.

Tous droits réservés 


\title{
John Curtis, Nigel Tallis. The Horse. From Arabia to Royal Ascot
}

\author{
Astrid Nunn
}

\section{RÉFÉRENCE}

John Curtis, Nigel Tallis. The Horse. From Arabia to Royal Ascot. London, British Museum Press, 2012, 268 p. et de nombreuses illustrations.

1 Ce catalogue a accompagné une exposition avec nombre d'objets provenant d'Arabie Saoudite ce qui a encore une valeur de rareté. Au centre de cette exposition se trouvait l'histoire du cheval dans le monde méditerranéen et tout particulièrement dans le contexte de l'Arabie Saoudite à partir de sa domestication vers 3500 av. J.-C. Une des raisons de l'intérêt du cheval en Arabie Saoudite est la découverte à al-Maqar de petites sculptures en pierre - peut-être - chevalines et qui seraient préhistoriques selon le Département des Antiquités de Riyad. Dans le matériel exposé du Proche Orient ancien se trouvaient aussi quelques objets achéménides du British Museum - et non des moindres, puisque le charriot du trésor d'Oxus en faisait partie. Ce catalogue termine par l'apport des chevaux arabes à l'élevage chevalin en Grande Bretagne et l'engouement de ce pays pour le sport équestre.

\section{AUTEURS}

\section{ASTRID NUNN}

Université de Munich 